\title{
Egg recovery from the vagina of the rabbit treated with prostaglandin $\mathbf{F}_{2 \alpha}$
}

\author{
TAKedA, Tetsuo, Hiroyuki SuzukI, Yutaka \\ Terami and Yoshio Tsutsumi \\ Department of Animal Science, Faculty of Agriculture, \\ Holkkido University, Sapporo 060, Japan
}

\begin{abstract}
Summary. The egg recovery from the vagina was conducted 1 to 48 hours after administration of 2 or $5 \mathrm{mg} / \mathrm{kg}$ of body weight of prostaglandin $\mathrm{F}_{2 \alpha}\left(\mathrm{PGF}_{2 \alpha}\right)$ in rabbits. The majority of eggs were recovered within 24 hours after treatment, especially more than $30 \%$ of the eggs were recovered by 2 hours after treatment, when a single administration of $\mathrm{PGF}_{2 \alpha}$ was made 20 to 28 hours after mating. A high recovery rate $(82.7 \pm$ $5.3 \%$ ) was obtained by a subcutaneous injection of $5 \mathrm{mg} / \mathrm{kg}$ of $\mathrm{PGF}_{2 \alpha} 22$ hours after mating. The earliest eggs were recovered from the vagina at the first vaginal washing 1 hour after treatment.

Multiple administrations of 2 or $5 \mathrm{mg} / \mathrm{kg}$ of $\mathrm{PGF}_{2 \alpha} 72$ to 114 hours after mating were applied to recover the blastocysts. However, only a scanty number of eggs were recovered following the $\mathrm{PGF}_{2 \alpha}$ administrations. Only $28.1 \pm 16.4 \%$ of the eggs were recovered from the vagina following the injections of $5 \mathrm{mg} / \mathrm{kg}$ of $\mathrm{PGF}_{2 \alpha}$ at 96,99 and 102 hours after mating. High implantation rates were demonstrated in spite of the multiple injections of $\mathrm{PGF}_{2 \alpha}$ except in one group in which $5 \mathrm{mg} / \mathrm{kg}$ of $\mathrm{PGF}_{2 \alpha}$ were applied at 108, 111 and 114 hours after mating. This fact indicates that the treatments with $\mathrm{PGF}_{2 \alpha}$ on and after 3 days after mating have a lesser effect on the intrauterine egg transport than the early treatments 20 to 28 hours after mating.
\end{abstract}

(Japan. J. Anim. Reprod. 25 23 30, 1979)

\section{Introduction}

Egg recovery from the vagina in rabbits following the treatments with various chemical agents have been recently reported. For instance, administration of estrogen accelerated the egg transport through the oviduct ${ }^{1 \sim 8)}$, and caused expulsion of eggs into the vagina ${ }^{1 \sim 4,7,8)}$. The egg transport in the oviduct was also disturbed by an administration of gestagen before ovulation, and some of the eggs were discharged into the vagina, ${ }^{90}$. The eggs located in the vaginal lumen of progestin-treated rabbits were recovered nonsurgically ${ }^{11)}$. It has been demonstrated that an administration of prostaglandin $\mathrm{F}_{2 \alpha}\left(\mathrm{PGF}_{2 \alpha}\right)$ caused a rapid egg transport through the oviduct and resulted in an expulsion of eggs into the vagina ${ }^{12 \sim 20)}$. And the eggs were recovered from the vagina by the vaginal washing $\operatorname{method}^{7,8,11,19,20)}$ developed to normal young as a result of transferring the eggs into the recipient does ${ }^{7,8,18)}$. The vaginal washing method proposed by TSUTSUMI and TAKEDA ${ }^{21)}$ for egg recovery in rabbits may introduce new requisite information regarding the physiology of egg transport.

In our previous report ${ }^{20)}$, a maximal recovery rate of eggs from the vagina (54.8\%) was observed when $5 \mathrm{mg} / \mathrm{kg}$ of body weight of $\mathrm{PGF}_{2 \alpha}$ was administered at 24 hours after mating, and no eggs was recovered following a single injection of $2 \mathrm{mg} / \mathrm{kg}$ of $\mathrm{PGF}_{2 \alpha}$ at 72,84 or 96 hours after mating. It has been considered that the endogenous progesterone levels 
elevated with the lapse of time after mating may reduce the sensitivity of the oviduct and uterus to $\mathrm{PGF}_{2 \alpha}$.

The present study was designed to investigate the effect of $\mathrm{PGF}_{2 \alpha}$ administrations on the egg recovery from the vagina and on the implantations in the rabbits.

\section{Materials and Methods}

Sixty-eight adult Japanese white female rabbits were injected with $40 \mathrm{IU}$ of human chorionic gonadotropin (HCG) immediately after double mating with fertile males.

First experiment: Thirty-six rabbits were divided into 9 groups depending on the time of PGF ${ }_{2 \alpha}$ administration (Table 1). Each group, consisting of 4 does, received a single subcutaneous injection of $5 \mathrm{mg} / \mathrm{kg}$ of body weight of $\mathrm{PGF}_{2 \alpha}$ at $20,21,22,23,24,25,26,27$ or 28 hours after mating. To determine the precise time of the appearance of eggs in the vagina, in vivo vaginal washing $\mathrm{s}^{20)}$ were carried out $1,2,3,6,9,12,24,36$ and 48 hours after treatment (Fig. 1).

Second experiment: Thirty-two does were divided into 8 groups, each group consisting of 4 animals, according to dose and time of $\mathrm{PGF}_{2 \alpha}$ administration (Table 2). Each rabbit received multiple subcutaneous injections of 2 or $5 \mathrm{mg} / \mathrm{kg}$ of $\mathrm{PGF}_{2 \alpha} 72$ to 114 hours after mating to recover the blastocysts. The vaginal washings were carried out in each rabbit after the first injection of $\mathrm{PGF}_{2 \alpha}$ in a similar schedule as indicated in the first experiment (Fig. 2).

The animals were laparotomized 9 days after mating, and the numbers of corpora lutea and sites of implantation were recorded.

\section{Results}

Number of eggs recovered after treatment:

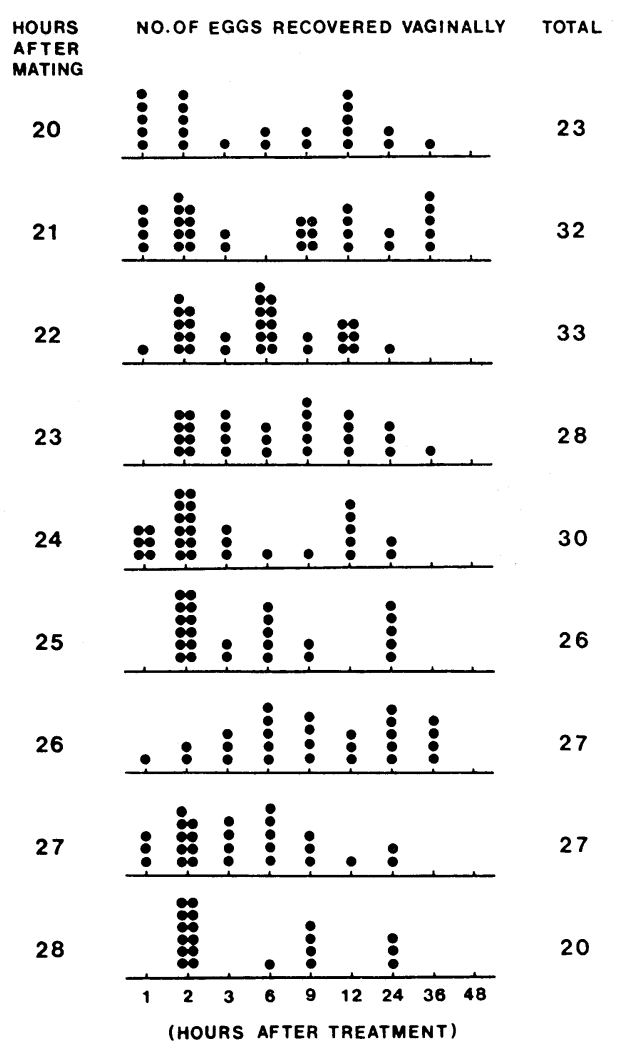

Fig. 1. Number of eggs recovered from the vagina in each hour following $5 \mathrm{mg} / \mathrm{kg}$ of $\mathrm{PGF}_{2 \alpha}$ treatment in the first experiment. Each group including four does.

- means an egg recovered.

A single administration of $5 \mathrm{mg} / \mathrm{kg}$ of $\mathrm{PGF}_{2 \alpha}$ at 22 hours after mating showed a high recovery rate of vaginal eggs based on the number of corpora lutea (about $83 \%$, range 64.3 90.0\%). There were no statistical differences in the recovery rates among groups in the first experiment, although the recovery rates were relatively low in the groups which were treated with $\mathrm{PGF}_{2 \alpha}$ at 20 or 28 hours after mating. The earliest eggs were recovered from the vagina only 1 hour following the treatment in most of the groups (Fig. 1), and 22.2 to $70.0 \%$ of eggs were recovered during the first 3 hours after the treatment; namely, 


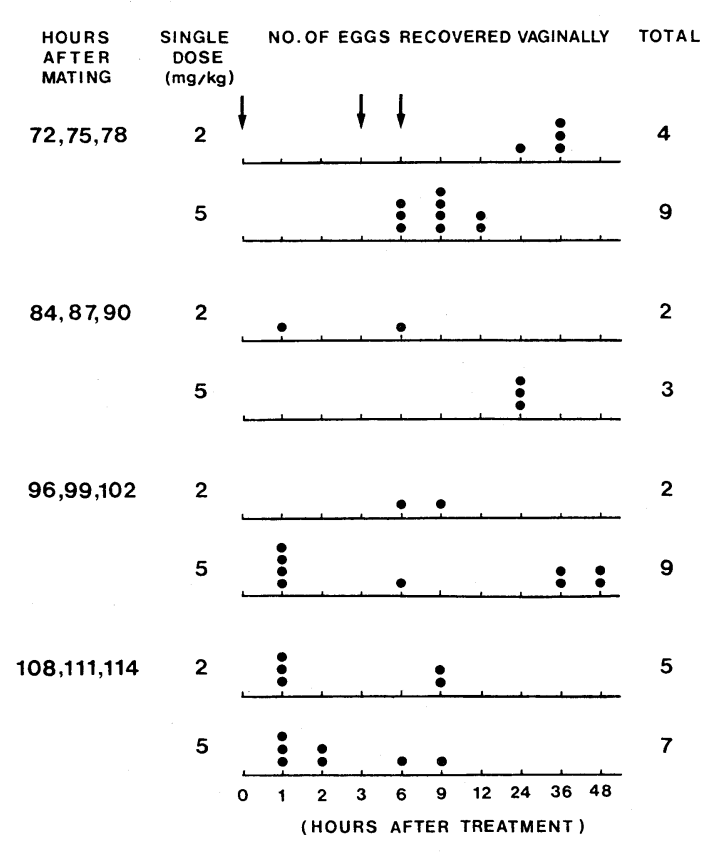

Fig. 2. Number of eggs recovered from the vagina in each hour following $\mathrm{PGF}_{2 \alpha}$ treatments in the second experiment. Each group including four does.

- means an egg recovered.

$\downarrow$ means $\mathrm{PGF}_{2 \alpha}$ injection.

$48 \%$ for the treatment at 20 hours after mating, $47 \%$ for 21 hours, $36 \%$ for 22 hours, $43 \%$ for 23 hours, $70 \%$ for 24 hours, $54 \%$ for 25 hours, $22 \%$ for 26 hours, $59 \%$ for 27 hours and $60 \%$ for 28 hours, respectively. No difference was observed statistically in the implantation rates among the groups, although the treatment at 22 hours after mating showed the lowest implantation rate $(1.8 \%$, range 0.0 $\sim 7.1 \%)$. The implantation rates were on a similar level (19.2 23.2\%) within the groups in which $\mathrm{PGF}_{2 \alpha}$ were given at $20,23,24,26$ or 27 hours after mating. The rates of eggs missed, which was calculated on the number of corpora lutea, showed similar figures except for the groups treated at 27 and 28 hours after mating. The rate of eggs missed was highest in the group of 28 hour-treatment
$(41.1 \%)$ and the rate was lowest $(6.4 \%)$ in the group of 27 hour-treatment (Table 1).

Multiple administrations of 2 or $5 \mathrm{mg} / \mathrm{kg}$ of $\mathrm{PGF}_{2 \alpha}$ in the second experiment led to unsatisfactory results. The number and the recovery rates of eggs from the vagina were remarkably low in both treatments of 2 and $5 \mathrm{mg} / \mathrm{kg}$ (Table 2, Fig. 2), and a few eggs were sporadically recovered during the experimental period (Fig. 2). However, the earliest eggs were recovered in the first vaginal washing 1 hour after the treatments in a half of 8 groups, also. A maximal egg recovery rate in the second experiment was $28 \%$ (range $0.0 \sim 75.0 \%$ ) in a group treated with $5 \mathrm{mg} / \mathrm{kg}$ of $\mathrm{PGF}_{2 \alpha} 96,99$ and 102 hours after mating (Table 2), the rate was remarkably low in comparison with the results of the first experiment treated with a single dosage (Table 1). The animals, in which no eggs were recovered from the vagina, were included in all groups of the second experiment. Especially when 2 and $5 \mathrm{mg} / \mathrm{kg}$ of $\mathrm{PGF}_{2 \alpha}$ were given 72,75 and 78 hours after mating and 84, 87 and 90 hours after mating, eggs were recovered from only one doe, respectively. Although groups given $5 \mathrm{mg} / \mathrm{kg}$ of $\mathrm{PGF}_{2 \alpha} 96$, 99 and 102 hours after mating and 108, 111 and 114 hours after mating showed low implantation rates of eggs $(21.9 \%$ and $5.0 \%$, respectively), more than $50 \%$ of eggs implanted in other groups.

Developmental stages of eggs recovered: In the first experiment, 246 eggs were recovered from the vagina following a single dose of $\mathrm{PGF}_{2 \alpha} 20$ to 28 hours after mating. Most eggs were morphologically normal and fertilized $(92.3 \%)$, and the proportion of 2-cell eggs against the total number of fertilized eggs were $32 \%$, and $36 \%$ for 4 -cell eggs, $21.5 \%$ for 8-cell to 32-cell eggs. A few degenerating eggs and empty zona pellucida were also re- 
Table 1. Egg recovery from the vagina and implantation of eggs following $5 \mathrm{mg} / \mathrm{kg}$ of $\mathrm{PGF}_{2 \alpha}$ treatment

\begin{tabular}{|c|c|c|c|c|c|c|c|c|c|}
\hline \multirow{2}{*}{$\begin{array}{c}\begin{array}{c}\mathrm{Time}^{\mathrm{a})} \\
\text { of } \\
\text { treatment }\end{array} \\
20\end{array}$} & \multirow{2}{*}{$\begin{array}{c}\begin{array}{c}\text { No. of } \\
\text { rabbits }\end{array} \\
4\end{array}$} & \multicolumn{2}{|c|}{$\begin{array}{c}\text { No. of } \\
\text { corpora lutea } \\
\text { Mean } \pm \text { S. E. } \\
\text { (range) }\end{array}$} & \multicolumn{2}{|c|}{$\begin{array}{l}\text { No. and rate of } \\
\text { egg recovery } \\
\text { (range, \%) }\end{array}$} & \multicolumn{2}{|c|}{$\begin{array}{l}\text { No. and rate of } \\
\text { implantation } \\
\text { of eggs } \\
\text { (range, \%) }\end{array}$} & \multicolumn{2}{|c|}{$\begin{array}{l}\text { No. and rate of } \\
\text { eggs missed } \\
\text { (range, \%) }\end{array}$} \\
\hline & & 44 & $11.0 \pm 0.7$ & 23 & $\begin{array}{c}52.0 \pm 10.2 \\
(18.2 \sim 61.5)\end{array}$ & 9 & $\begin{array}{l}21.0 \pm 15.7 \\
(0.0 \sim 72.7)\end{array}$ & 12 & $\begin{array}{l}27.0 \pm 5.5 \\
(9.1 \sim 38.5)\end{array}$ \\
\hline 21 & 4 & 46 & $\underset{(11 \sim 13)}{11.5 \pm 0.4}$ & 32 & $\begin{array}{c}72.0 \pm 16.7 \\
(15.4 \sim 100.0)\end{array}$ & 2 & $\begin{array}{l}4.6^{\mathrm{b})} \\
(0.0 \sim 18.2)\end{array}$ & 12 & $\begin{array}{l}23.4 \pm 16.8 \\
(0.0 \sim 84.6)\end{array}$ \\
\hline 22 & 4 & 41 & $\begin{array}{c}10.3 \pm 1.1 \\
(9 \sim 14)\end{array}$ & 33 & $\begin{array}{c}82.7 \pm 5.3 \\
(64.3 \sim 90.0)\end{array}$ & 1 & $\begin{array}{l}1.8^{\mathrm{b})} \\
(0.0 \sim 7.1)\end{array}$ & 7 & $\begin{array}{c}15.5 \pm 4.0 \\
(10.0 \sim 28.6)\end{array}$ \\
\hline 23 & 4 & 50 & $\begin{array}{l}12.5 \pm 1.5 \\
(9 \sim 16)\end{array}$ & 28 & $\begin{array}{c}57.1 \pm 4.2 \\
(46.7 \sim 70.0)\end{array}$ & 9 & $\begin{array}{l}19.2 \pm 7.3 \\
(0.0 \sim 33.3)\end{array}$ & 13 & $\begin{array}{c}22.2 \pm 4.8 \\
(11.1 \sim 37.5)\end{array}$ \\
\hline 24 & 4 & 47 & $\begin{array}{c}11.8 \pm 1.1 \\
(9 \sim 14)\end{array}$ & 30 & $\begin{array}{c}63.8 \pm 2.8 \\
(60.0 \sim 71.4)\end{array}$ & 10 & $\begin{array}{c}21.5 \pm 4.8 \\
(10.0 \sim 33.3)\end{array}$ & 7 & $\begin{array}{l}14.6 \pm 5.3 \\
(0.0 \sim 30.0)\end{array}$ \\
\hline 25 & 4 & 41 & $\begin{array}{c}10.3 \pm 0.7 \\
(8 \sim 12)\end{array}$ & 26 & $\begin{array}{c}62.6 \pm 7.5 \\
(45.5 \sim 80.0)\end{array}$ & 6 & $\begin{array}{l}\left.13.6^{\mathrm{b}}\right) \\
(0.0 \sim 54.5)\end{array}$ & 9 & $\begin{array}{c}23.8 \pm 8.9 \\
(0.0 \sim 50.0)\end{array}$ \\
\hline 26 & 4 & 43 & $\begin{array}{c}10.8 \pm 0.5 \\
(9 \sim 12)\end{array}$ & 27 & $\begin{array}{c}62.6 \pm 3.3 \\
(55.6 \sim 72.7)\end{array}$ & 8 & $\begin{array}{l}20.2 \pm 6.2 \\
(0.0 \sim 44.4)\end{array}$ & 8 & $\begin{array}{l}17.2 \pm 7.8 \\
(0.0 \sim 45.5)\end{array}$ \\
\hline 27 & 4 & 36 & $\begin{array}{l}9.0 \pm 1.5 \\
(6 \sim 14)\end{array}$ & & $\begin{array}{c}70.4 \pm 8.6 \\
(50.0 \sim 88.9)\end{array}$ & 6 & $\begin{array}{l}23.2 \pm 11.7 \\
(0.0 \sim 50.0)\end{array}$ & 3 & $\begin{array}{r}6.4 \pm 3.7^{\mathrm{c})} \\
(0.0 \sim 14.3)\end{array}$ \\
\hline 28 & 4 & 37 & $\begin{array}{c}9.3 \pm 0.2 \\
(9 \sim 10)\end{array}$ & 20 & $\begin{array}{c}53.3 \pm 8.6 \\
(33.3 \sim 80.0)\end{array}$ & 2 & $\begin{array}{l}5.6^{\mathrm{b})} \\
(0.0 \sim 22.2)\end{array}$ & 15 & $\begin{array}{l}41.1 \pm 10.2^{\mathrm{d})} \\
(20.0 \sim 66.6)\end{array}$ \\
\hline
\end{tabular}

a): Hours after mating.

b): Figure showed in one doe.

c),d): Significant differences were noted between $c$ and $d(p<0.05)$.

Table 2. Egg recovery from the vagina and implantation of eggs following multiple injection of 2 or $5 \mathrm{mg} / \mathrm{kg} \mathrm{PGF}_{2 \alpha}$

\begin{tabular}{|c|c|c|c|c|c|c|c|c|}
\hline $\begin{array}{l}\text { Time } e^{a} \text { of } \\
\text { treatment }\end{array}$ & $\begin{array}{c}\text { Doses } \\
\text { of } \mathrm{PGF}_{2 \alpha} \\
(\mathrm{mg} / \mathrm{kg})\end{array}$ & $\begin{array}{l}\text { No. of } \\
\text { rabbits }\end{array}$ & & $\begin{array}{l}\text { No. of } \\
\text { corpora lutea } \\
\text { (range) }\end{array}$ & & $\begin{array}{l}\text { and rate of } \\
\text { gg recovery } \\
\text { (range, \%) }\end{array}$ & $\begin{array}{l}\text { No. and rate of } \\
\text { implantations } \\
\text { (range, \%) }\end{array}$ & $\begin{array}{l}\text { No. and rate of } \\
\text { eggs missed } \\
\text { (range, \%) }\end{array}$ \\
\hline \multirow[t]{2}{*}{$72,75,78$} & $2 \times 3$ & 4 & 48 & $\begin{array}{r}12.0 \pm 1.2 \\
(10 \sim 14)\end{array}$ & 3 & $\begin{array}{l}5.4^{\mathrm{b})} \\
(0.0 \sim 21.4)\end{array}$ & $34 \quad \begin{array}{r}72.9 \pm 8.5 \\
(50.0 \sim 90.0)\end{array}$ & $11 \begin{array}{c}21.8 \pm 4.4 \\
(10.0 \sim 21.4)\end{array}$ \\
\hline & $5 \times 3$ & 4 & 57 & $\begin{array}{r}14.3 \pm 4.7 \\
(13 \sim 15)\end{array}$ & 9 & $\begin{array}{l}16.1^{\mathrm{b})} \\
(0.0 \sim 64.3)\end{array}$ & $\begin{array}{ll}36 \quad 63.2 \pm 20.2^{\mathrm{d})} \\
(7.1 \sim 64.3)\end{array}$ & $12 \quad \begin{array}{l}\left.19.3 \pm 9.1^{\mathrm{f}}\right) \\
(0.7 \sim 40.0)\end{array}$ \\
\hline \multirow[t]{2}{*}{$84,87,90$} & $2 \times 3$ & 4 & 37 & $\begin{array}{c}9.3 \pm 1.4 \\
(6 \sim 13)\end{array}$ & 2 & $\begin{array}{l}\left.5.6^{\mathrm{b}}\right) \\
(0.0 \sim 22.2)\end{array}$ & $21 \begin{array}{c}51.4 \pm 18.4 \\
(11.1 \sim 100.0)\end{array}$ & 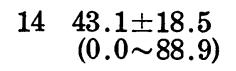 \\
\hline & $5 \times 3$ & 4 & 34 & $\begin{array}{r}8.5 \pm 1.3 \\
(6 \sim 12)\end{array}$ & 3 & $\begin{array}{l}12.5^{\mathrm{b})} \\
(0.0 \sim 50.0)\end{array}$ & $24 \quad \begin{array}{r}70.0 \pm 17.1^{\mathrm{d})} \\
(33.3 \sim 100.0)\end{array}$ & $\begin{array}{ll}7 \quad 22.9 \pm 13.7^{\mathrm{f})} \\
(0.0 \sim 62.5)\end{array}$ \\
\hline \multirow[t]{2}{*}{$96,99,102$} & $2 \times 3$ & 4 & 43 & $\begin{array}{c}10.8 \pm 0.3 \\
(10 \sim 11)\end{array}$ & 2 & $\begin{array}{c}4.8 \pm 2.8 \\
(0.0 \sim 10.0)\end{array}$ & $\begin{array}{cc}28 & 64.1 \pm 17.4 \\
& (20.0 \sim 100.0)\end{array}$ & $13 \quad \begin{array}{c}31.2 \pm 16.3 \\
(0.0 \sim 70.0)\end{array}$ \\
\hline & $5 \times 3$ & 4 & 32 & $\begin{array}{l}\left.8.0^{c}\right) \\
(8.0)\end{array}$ & 9 & $\begin{array}{c}28.1 \pm 16.4 \\
(0.0 \sim 75.0)\end{array}$ & $\begin{array}{l}7 \quad 21.9 \pm 10.7 \\
(0.0 \sim 50.0)\end{array}$ & $16 \begin{array}{r}50.0 \pm 15.3 \\
(25.0 \sim 87.5)\end{array}$ \\
\hline \multirow[t]{2}{*}{$108,111,114$} & $2 \times 3$ & 4 & 41 & $\begin{array}{c}10.3 \pm 0.5 \\
(9 \sim 11)\end{array}$ & 5 & $\begin{array}{l}12.9 \pm 8.0 \\
(0.0 \sim 33.3)\end{array}$ & $21 \quad \begin{array}{l}51.9 \pm 19.2 \\
(0.0 \sim 90.9)\end{array}$ & $15 \quad \begin{array}{l}35.2 \pm 19.0 \\
(0.0 \sim 81.8)\end{array}$ \\
\hline & $5 \times 3$ & 4 & 37 & $\begin{array}{c}9.3 \pm 0.5 \\
(8 \sim 11)\end{array}$ & 7 & $\begin{array}{l}20.0 \pm 15.8 \\
(0.0 \sim 50.0)\end{array}$ & $\begin{array}{ll}2 & 5.0^{\mathrm{b}), \mathrm{e})} \\
& (0.0 \sim 20.0)\end{array}$ & $28 \begin{array}{r}75.0 \pm 14.4^{\mathrm{g})} \\
(50.0 \sim 100.0)\end{array}$ \\
\hline
\end{tabular}

a): Hours after mating.

b): Figure showed in one doe.

c): Each doe had 8 corpora lutea equally.

d),e): Significant differences were noted between $d$ and $e(p<0.05)$.

${ }^{\mathrm{f}), \mathrm{g})}$ : Significant differences were noted between $\mathrm{f}$ and $\mathrm{g}(\mathrm{p}<0.05)$. 
Table 3. Developmental stages of eggs recovered from the vagina following the PGF $\mathrm{P}_{2 \alpha}$ treatment in the first experiment

\begin{tabular}{|c|c|c|c|c|c|c|c|c|c|c|}
\hline \multirow{2}{*}{ Morphology of eggs } & \multicolumn{9}{|c|}{ Time of $\mathrm{PGF}_{2 \alpha}$ (hours after mating) } & \multirow{2}{*}{ Tota } \\
\hline & 20 & 21 & 22 & 23 & 24 & 25 & 26 & 27 & 28 & \\
\hline Undivided $^{\text {a) }}$ & 11 & 5 & 5 & & & & & & & 21 \\
\hline Unfertilized & & 1 & & 1 & & 5 & 1 & & & 8 \\
\hline 2-cell & 2 & 9 & 9 & 13 & 15 & 6 & 4 & 12 & 2 & 72 \\
\hline 4-cell & 4 & 8 & 14 & 6 & 9 & 11 & 9 & 9 & 11 & 81 \\
\hline 8-cell & 4 & 1 & 1 & 3 & 4 & 1 & 5 & 4 & 5 & 28 \\
\hline 16-cell & & 2 & 1 & 3 & & 3 & 4 & 2 & 1 & 16 \\
\hline 32-cell & & 5 & & & & & 3 & & 1 & 9 \\
\hline Degenerating & 2 & & & 2 & & & & & & 4 \\
\hline Empty zona pellucida & & 1 & 3 & & & 2 & & 1 & & 7 \\
\hline
\end{tabular}

a): The mono-cell egg having 2 polar bodies was classified as undivided eggs.

Table 4. Developmental stages of eggs recovered from the vagina following the PGF $2 \alpha$ treatments in the second experiment

\begin{tabular}{|c|c|c|c|c|c|c|c|c|c|}
\hline \multirow{3}{*}{$\begin{array}{c}\text { Morphology of } \\
\text { eggs }\end{array}$} & \multicolumn{8}{|c|}{ Time of $\mathrm{PGF}_{2 \alpha}$ (hours after mating) and doses $(\mathrm{mg} / \mathrm{kg})$} & \multirow{3}{*}{ Tota } \\
\hline & \multicolumn{2}{|c|}{$72,75,78$} & \multicolumn{2}{|c|}{$84,87,90$} & \multicolumn{2}{|c|}{$96,99,102$} & \multicolumn{2}{|c|}{$108,111,114$} & \\
\hline & $2 \times 3$ & $5 \times 3$ & $2 \times 3$ & $5 \times 3$ & $2 \times 3$ & $5 \times 3$ & $2 \times 3$ & $5 \times 3$ & \\
\hline Morula & & 8 & & & & & & & 8 \\
\hline Blastocyst & & 1 & 2 & 3 & 2 & $2^{a)}$ & 5 & 6 & 21 \\
\hline \multicolumn{10}{|l|}{ Degenerating } \\
\hline morula & 4 & & & & & & & & 4 \\
\hline blastocyst & & & & & & 7 & & 1 & 8 \\
\hline
\end{tabular}

a): Two blastocysts revealed expanding to about 289 and 387 micra in diameters.

covered $(4.5 \%)$. Twenty-one undivided eggs were recovered after an injection of $\mathrm{PGF}_{2 \alpha} 20$ to 22 hours after mating, these eggs were considered as the fertilized eggs because having 2 polar bodies (Table 3). All eggs recovered in the second experiment were in the morula or blastocyst stages (Table 4). Twelve eggs (29\%) were degenerated and others were morphologically normal. Two expanding blastocysts, about 289 and 387 micra in diameter, respecti vely, were recovered one hour after $\mathrm{PGF}_{2 \alpha}$ treatment of $5 \mathrm{mg} / \mathrm{kg} 96$ hours after mating (Table 4).

\section{Discussion}

In our previous report ${ }^{20)}$ we have demon- strated that $48.4 \%$ and $54.8 \%$ of eggs were recovered from the vagina in rabbits, when 2 or $5 \mathrm{mg} / \mathrm{kg}$ of body weight of $\mathrm{PGF}_{2 \alpha}$ were injected 24 hours after mating and the vaginal washing was started 3 hours after the treatment. But no eggs was recovered when 2 $\mathrm{mg} / \mathrm{kg}$ was administered at 72,84 or 96 hours after mating, although a few eggs were recovered following $5 \mathrm{mg} / \mathrm{kg}$ treatment. The present study clearly showed that an expulsion of eggs into the vagina occurred within 1 hour after $\mathrm{PGF}_{2 \alpha}$ treatment and high recovery rates of eggs were observed following a single administration of $5 \mathrm{mg} / \mathrm{kg}$ of $\mathrm{PGF}_{2 \alpha} 20$ to 28 hours after mating. The present study also demonstrated that the majority of eggs were 
recovered within 24 hours after treatment, especially more than $30 \%$ of the eggs were recovered 2 hours after treatment in total (Table 1, Fig. 1). In our preliminary experiment concerning about the retention of eggs in the vagina of $\mathrm{PGF}_{2 \alpha}$-treated rabbits, when known number of surrogates of the eggs were deposited into the proximal part of the vagina 24 hours after mating following an injection of $5 \mathrm{mg} / \mathrm{kg}$ of $\mathrm{PGF}_{2 \alpha}$ immediately after deposition, the recovery rate of the surrogates from the vagina 1,3 and 6 hours later were $42 \%, 25 \%$ and $6 \%$, respectively. Thus, the expulsion of eggs into the vagina was remarkable within a few hours after $\mathrm{PGF}_{2 \alpha}$ treatment.

It has been reported that the subcutaneous injection of $\mathrm{PGF}_{2 \alpha}$ in rabbits increased the frequency and amplitude of oviductal contraction for 1 to 1.5 hours $^{22)}$ or for 3.4 hours $^{23)}$. In the present study, eggs were continuously recovered from the vagina up to 36 hours after the treatment, although the egg recovery rate was remarkably high at the second hour after the treatment. This indicates that the egg transport accelerated by $\mathrm{PGF}_{2 \alpha}$ is kept for long time over the effective period of $\mathrm{PGF}_{2 \alpha}$ on oviductal contractility.

Multiple injections of 2 or $5 \mathrm{mg} / \mathrm{kg}$ of $\mathrm{PGF}_{2 \alpha}$ 72 to 114 hours after mating on the recovery of the intrauterine blastocysts were examined in the second experiment, because only a few eggs were recovered by a single injection of 2 or $5 \mathrm{mg} / \mathrm{kg}$ of $\mathrm{PGF}_{2 \alpha}$ at 72,84 or 96 hours after mating in the previous experiment ${ }^{20)}$. A slight improvement in the recovery rate was observed in the present study, although the time of the vaginal washing was altered. However, the rate of eggs recovered from the vagina in the second experiment was remarkably low compared with that observed in the first experiment. This may be caused by a progestational condition which eliminates the effect of $\mathrm{PGF}_{2 \alpha}$ on uterine contractions. It has been reported that the sensitivity of muscles to $\mathrm{PGF}_{2 \alpha}$ is influenced by endocrine conditions ${ }^{24,25)}$, and that the concentration of PGF in the oviduct is decreased by progesterone treatment ${ }^{26)}$ and the response of oviducts of $\mathrm{PGF}_{2 \alpha}$ is decreased by progesterone ${ }^{25)}$. Also, it has been indicated that the uterine response to $\mathrm{PGF}_{2 \alpha}$ in progesterone-treated rabbits was significantly reduced ${ }^{27)}$. Thus, the endogenous progesterone level increased with the lapse of time after mating ${ }^{28)}$ may depress the sensitivity of the oviduct and uterus to $\mathrm{PGF}_{2 \alpha}$, and this may cause a reduction of the number of the eggs expelled into the vagina. It seems, however, that the expulsion of intrauterine eggs into the vagina via cervix after $\mathrm{PGF}_{2 \alpha}$ injections is not only depending on the enhanced uterine contractions induced by $\mathrm{PGF}_{2 \alpha}$ but also may be related to the size of the blastocysts, because of the low recovery rate of blastocysts in the second experiment. It is speculated that the expansion of blastocysts may cause to prevent physically the transport of the blastocysts into the vagina through the cervix. There are no reports concerning the egg transport through the cervix, although the histological structures of the nonpregnant ${ }^{2 \theta)}$ and the pregnant rabbit ${ }^{30)}$ were demonstrated. In the present study, two expanding blastocysts (289 and 387 micra in diameter) were recovered from the vagina 1 hour after treatment in the case of $5 \mathrm{mg} / \mathrm{kg}$ administered 96 hours after mating (Table 4). This may indicate that the cervical cannal was relaxed in some degree to allow the passage of the blastocysts after $\mathrm{PGF}_{2 \alpha}$ treatment, and the size of the blastocysts may be the limit for the egg transport through the cervix because more largely expanding blastocysts have never been 
recovered from the vagina when $5 \mathrm{mg} / \mathrm{kg}$ of $\mathrm{PGF}_{2 \alpha}$ was given 108, 111 and 114 hours after mating. According to $\mathrm{ADAMS}^{31)}$, the correct timing of the entry of eggs into the uterus is vitally important for their further survival, and if eggs prematurely enter into the uterus, the eggs are quickly transported through the uterus and are expelled into the vagina. ADAMS $^{32)}$ also confirmed that in estrous rabbits, eggs transferred to the uterus were immediately expelled into the vagina and that the percentages of eggs recovered from the uterus fell from $69 \%$ to $0 \%$ after 0.5 to 4 hours after transfer. It was reported that unfertilized eggs in pseudopregnant rabbit appeared in the vagina more than 90 hours after sterile mating, and that the mean diameters of these eggs were $335 \sim 362$ micra $^{21)}$. This indicates that the cervical cannal may relaxed in some degree and that eggs in unsufficient diameters may pass through the cervix to the vagina. HODGSON and PAUERSTEIN ${ }^{33)}$ reported that some eggs were found in the uterus and vagina of normal rabbit 48 hours after mating and HCG administration. Thus, it assumed that the treatment of $\mathrm{PGF}_{2 \alpha}$ around 24 hours after mating causes the expulsion of eggs into the vagina.

Acknowledgment. The authors are grateful to Fuji Chemical Industries LTD., Tokyo, Japan, for supplying the prostaglandin $F_{2 \alpha}$. This work was supported in part by a Research Project Grant (Project No. 348063) from the Ministry of Education, Japan.

\section{References}

1) Chang, M. C.: Endocrinology 79, 939, 1966.

2) Chang, M. C.: Nature 212, 1048, 1966.

3) Chang, M. C. \& R. Yanagimachi: Fertil. Steril. 16, 281, 1965.

4) Chang, M. C. \& M. J. K. Harper: Endocrinology 78, 860, 1966.

5) Greenwald, G. S.: J. exp. Zool. 135, 461, 1957.

6) Greenwald, G. S.: Fertil. Steril. 10, 155,
1959.

7) Tsutsumi, Y., T. Takeda, K. Yамamoto \& Y. TANABE: J. Reprod. Fertil. 48, 393, 1976.

8) Takeda, T., K. Yamamoto, Y. Tanabe \& Y. Tsutsumi: Memoris Facul. Agr. Hokkaido Univ. 10, 231, 1977.

9) Chang, M. C.: Endocrinology 81, 1251, 1967.

10) Pauerstein, C. J., B. D. Fremming \& J. E. MARTIN: Gynec. Invest. 1, 257, 1970.

11) Takeda, T., H. Suzuki, S. Matsui, Y. Terami \& Y. Tsutsumi: Japan. J. Anim. Reprod. 24, 184, 1978.

12) Ellinger, J. V.\& K. T. Kirton: Biol. Reprod. 7, 106, 1972 (abstr.).

13) Ellinger, J. V. \& K. T. Kirton: Biol. Reprod. 11, 93, 1974

14) Chang, M. C. \& D. M. Hunt: Nature 236, 120 , 1972.

15) Chang, M. C., D. M. Hunt \& C. Polge: $A d v$. Biosci. 9, 805, 1973.

16) Chang, M. C., S. K. Saksena \& D. M. Hunt: Prostaglandins 5, 341, 1974.

17) AReF, I., E. S. E. HAFEz \& G. A. R. KamaR: Fertil. Steril 24, 671, 1973.

18) AREF, I. \& E. S. E. HAFEZ: In Ovum Transport and Fertility Regulation (HARPER, M.J.K., C. J. Pauerstein, C. E. Adams, E. M Coutinho, H. B. Croxatto \& D. N. Paton eds.) p. 320, Copenhagen, Scriptor, 1976.

19) Takeda, T., Y. Tsutsumi, Y. Tanabe \& K. Yамамото: Fertil. Steril. 28, 759, 1977.

20) Takeda, T., Y. Tsutsumi, S. Hara \& M. IDa: Fertil. Steril. 30, 79, 1978.

21) TsuTsumi, Y. \& T. TAKedA: Jap. J. Zootech. Sci. 47, 509, 1976.

22) Spilman, C. H. \& M. J. K. Harper: Biol. Reprod. 7, 106, 1972 (abstr.).

23) Spilman, C. H. \& M. J. K. HarPer: Biol. Reprod. 9, 36, 1973.

24) Horton, E. W., I. H. M. Main \& C. J. ThoMPSON: J. Physiol. (Lond.) 180, 514, 1965.

25) Spilman, C. H.: Prostaglandins 7, 465, 1974.

26) Saksena, S. K. \& M. J. K. HARPeR: Biol Reprod. 13, 68, 1975.

27) Porter, D. G. \& H. R. Behrman: Nature 232, 627, 1971.

28) Hilliard, J. \& L. W. M. Eaton Jr.: Endocrinology 89, 522, 1971.

29) Suzuki, H., T. Takeda \& Y. Tsutsumi: Jap. J. Zootech. Sci. 49. 614, 1978.

30) Tyler, K. R.: J. Reprod. Fertil. 49, 341, 1977.

31) Adams, C. E.: In Ciba Foundation Symposium; Preimplantation Stages of Pregnancy (WoLSTENHOLME, G. E. W. \& M. O'ConNor eds.) p. 345, J. \& A. Churchill, London, 1965. 
32) Adams, C. E.: Adv. Biosci. 4, 149, 1969.

33) Hodgson, B. J. \& C. J. Pauerstein: Biol. Re- prod. 14, 377, 1976.

(Received August 31, 1978)

\section{Prostaglandin $\mathrm{F}_{2 \alpha}$ 投与家鬼胵からの採卵 \\ 武田哲男・鈴木裕之・寺見 裕・堤 義雄 (北海道大学農学部 畜産学科)}

不娃性交配後 90 時間目以降の家鬼臸から未受精卵子 が回収され ${ }^{21)}$, estrogen ${ }^{7,8)}$ 及び $\mathrm{PGF}_{2 \alpha}$ 処理家鬼 ${ }^{19)} の$ 䐋から得られた卵子の一部が生存性を有することが知ら れた。 $\mathrm{PGF}_{2 \alpha}$ 投与が家鬼卵子の移動を促進することは 上く知られているが ${ }^{1220)}$, 前報20)で交配後 24 時間目に $\mathrm{PGF}_{2 \alpha}$ を生体重 $1 \mathrm{~kg}$ あたり $2 \mathrm{mg}$ または $5 \mathrm{mg}$ 投与 した時の胵からの採卵率は投与後 75 時間目までにそれ ぞれ 48.4\%，54.8\% に達したが，交配後 72 時間目以 後の処理では $2 \mathrm{mg} / \mathrm{kg}$ の場合全く卵子は採取されず, $5 \mathrm{mg} / \mathrm{kg}$ 投与で少数の卵子が採取されたにすぎなかっ た。本研究では交配後 20 時間目から 28 時間目の家鬼 に $\mathrm{PGF}_{2 \alpha}$ を 1 回投与し, その後の胵からの採卵率と着 床摔を㛟討するとともに, 交配後 72 時間目から 108 時 間目の家鬼について 3 回の反復投与を行い, 腔からの採 卵率の改善を試みた。実験 1 では 36 羽の雌家鬼を投与 時間により 9 啡に分け, 交配後 20 時間目から 28 時間目 にかけて $5 \mathrm{mg} / \mathrm{kg}$ の $\mathrm{PGF}_{2 \alpha}$ を 1 回注射した (䛾 1)。 実験 2 では 32 羽の家鬼を投与時間と投与量により 8 群 に分け, 交配後 72 時間目から 108 時間目にかけて投与 を開始し,その後 3 時間ごとに 2 回反復投与した (図 2 , 表2)。
実験 1 では交配後 22 時間目に $5 \mathrm{mg} / \mathrm{kg}$ の $\mathrm{PGF}_{2 \alpha}$ を 投与した群が最も採卵数が多く, $82.7 \%$ の採卵率が得 られた。また，21 時間目での投与では $72.0 \%, 27$ 洔間 目の投与でも $70.4 \%$ と高い採卵率が示された (表 1 )。 $\mathrm{PGF}_{2 \alpha}$ 投与後 3 時間以内の卵子採取率をみると, 採取 卵子のうち 22 70\%がこの封間带に回収されている(図 1)。一方，これらのグループに抽羌着率はいずれ も低く, 最高 $23.2 \%$, 最低 $1.8 \%$ であった。

実験 2 では $2 \mathrm{mg} / \mathrm{kg}$ または $5 \mathrm{mg} / \mathrm{kg}$ を反復投与し たが，腔からの採卵率は低く, 交配後 96, 99, 102 時間 目に各 $5 \mathrm{mg} / \mathrm{kg}$ を投与した家鬼群で $28.1 \%$ の 採卵率 を得たにとどまった(表 2 )。その反面, 着床率は交配後 96, 99, 102 時間目に $5 \mathrm{mg} / \mathrm{kg}$ を投与したグループで $21.9 \%$ ，また交配後 $108,111,114$ 時問目に $5 \mathrm{mg} / \mathrm{kg}$ を 投与したグループが $5.0 \%$ と低かったほかは 50\% 以上 の着床率を示した。

以上の 結果から, 交配後 24 時間日前後での $\mathrm{PGF}_{2 \alpha}$ 投与は胵からの卵子採取にきわめて有効であったが，卵 子が子宮内に進入した後での $\mathrm{PGF}_{2 \alpha}$ 投与では, 総投与 量を増加しても腔からの採卵効果は少ないことが確認さ れた。 